\title{
Evaluation of MEWDS-like lesions with fluorescein angiography and its frequency at an ophthalmic emergency department in Rio de Janeiro
}

\author{
Avaliação de lesões com as características MEWDS ao exame de angiografia fluoresceínica e sua \\ prevalência em serviço de emergência oftalmológica no Rio de Janeiro
}

Lillian Abreu Dias ${ }^{1}$, Eduardo H. Morizot ${ }^{1,2}$

\begin{abstract}
Purpose: To characterize multiple evanescent white dot syndrome (MEWDS)-like lesions as diagnosed by clinical exam and fluorescein angiography (FA) to build an epidemiological profile of this disease and highlight the most common angiographical aspects. It is important to emphasize the existence of this syndrome and improve patients' information about the natural good course of this disease. Methods: A cross-sectional study including all FA performed from July 2006 to October $2012(6,111$ exams analyzed) in patients at our ophthalmic emergency department, with analysis of the different angiographic aspects of the MEWDS-diagnosed cases.

Results: Among the 6,111 angiographies analyzed, 15 MEWDS cases were detected; the patients ranged in age from 13 to 42 years old, and the male/female ratio was $60 \%$ to $40 \%$ (nine male and six female). The most common FA aspects included hyperfluorescent dots, dots and spots in the retinal mid-periphery, and foveal granularity in $46 \%$ of the cases.

Conclusions: MEWDS has a good prognosis, with spontaneous involution, which makes it difficult to diagnose because of the delayed access to ophthalmological assistance, in special FA examination, which highlights the lesions. This study was possible due to the quick access facility at a private ophthalmic emergency department and examination by an experienced ophthalmologist, along with complementary diagnosis by FA and better perception of the patients, thus ensuring good prognosis.
\end{abstract}

Keywords: Retina; Fluorescein angiography; Scotoma; Vision, low; Retinitis; Retinal diseases; Syndrome

\begin{abstract}
RESUMO
Objetivo: Foi determinada a prevalência de lesões similares as da síndrome dos pontos brancos evanescentes (MEWDS) diagnosticados à angiografia, traçando um perfil epidemiológico e destacando os principais aspectos angiográficos encontrados. 0 objetivo final visa a atentar o examinador menos experiente para identificação desta entidade clínica, muitas vezes subdiagnosticada, além de tranquilizar o paciente acerca do prognóstico da doença.

Método: Estudo transversal de todas as angiografias fluorescentes realizadas no período de julho de 2006 a outubro de 2012 (total de 6.111 exames), provenientes dos atendimentos de emergência oftalmológica sequidos de análise angiográfica. Assim, os casos diagnosticados como MEWDS foram estudados no que competeàs diferentes manifestações angiográficas desta doença.

Resultados: Dentre as 6.111 angiografias analisadas, de pacientes provenientes da emergência, foram detectados 15 casos de MEWDS, comperfil epidemiológico deidade variando entre 13 e 42 anos, sendo 9 homens (60\%) e 6 mulheres (40\%). Os aspectos angiográficos mais encontrados foram os pontos hiperfluorescentes difusos, pontos hiperfluorescentes associados a manchas hiperfluorescentes em média periferia, e aspecto foveal granulado, este último em aproximadamente metade dos casos (46\%). Conclusão:MEWDS possuibom prognóstico pela involução espontânea edificilmente é diagnosticada, devido ao retardo do acesso do paciente ao atendimento oftalmológico e, principalmente, à angiografia, que evidencia melhor as lesões. Este estudo tornou-se possivel em virtude da facilidade do acesso à emergência oftalmológica privada, além de avaliação por oftalmologista experiente e da complementação diagnóstica pela angiofluoresceinografia. O fechamento deste diagnóstico permite tranquilizar o paciente acerca da boa evolução do quadro, além de afastar causas de baixa visual de mau prognóstico.
\end{abstract}

Descritores: Retina; Angiofluoresceinografia; Escotoma; Baixavisão; Retinite;Doenças retinianas; Sindrome

\section{INTRODUCTION}

Multiple evanescent white dot syndrome (MEWDS) was first described by Jampol et al.(1), and in the same year by Takeda et al. ${ }^{(2)}$. Its pathophysiology is believed to be characterized mainly by photoreceptor layer disruption ${ }^{(3)}$. It is an uncommon choroidoretinal syndrome that usually presents as a unilateral multifocal retinitis, and more commonly affects women in a 4:1 female:male ratio ${ }^{(1,2)}$. Considering this information, we analyzed the fluorescein angiography (FA) data from the retina department and compared the data with the existing literature.

The symptoms usually start with flu-like complaints, followed by photopsias, scotomas, and low vision. Ophthalmoscopy is the most common diagnostic method, although FA, electroretinogram, visual field test, and optical coherence tomography (OCT) may also help to confirm the diagnosis.

The typical presentation of this syndrome includes the presence of multiple white dots at the fundus extending from the posterior pole to the near peripheral retina, with some cases followed by discrete vitritis and foveal granularity. The latter characteristic is highly indicative of MEWDS when associated with white dots and/or spots ${ }^{(4)}$.

MEWDS is often a self-limiting condition, which evolves to complete resolution and visual acuity recovery, although there may be retinal sequelae in a few cases $^{(4)}$.

Angiographic characteristics may vary in eyes with similar clinical signs of MEWDS. This variation may reveal the different anatomic structures involved during the natural course of the disease. The FA
Submitted for publication: March 31, 2015

Accepted for publication: May 13, 2015

Policlínica de Botafogo, Rio de Janeiro, RJ, Brazil.

Instituto Benjamin Constant, Rio de Janeiro, RJ, Brazil.
Funding: No specific financial support was available for this study.

Disclosure of potential conflicts of interest: None of the authors have any potential conflict of interest to disclose.

Corresponding author: Lillian Abreu Dias. Av. Dr. Cardoso de Melo, 1.046/83 - São Paulo, SP 04548-004 - Brazil - E-mail: lilliandias@gmail.com 
of the white dots exhibit a fine halo appearance in a wreath-like swirl configuration to some of the white dots, and this halo diffuses in the later stages of the angiogram, first developing a stippled pattern of fluorescence, and then becoming a diffuse white spot that only mildly leaks fluorescein. There may be fluorescein leakage from the optic nerve, and occasionally, there may be late staining of the retinal blood vessels due to a mild vasculitis. Incidentally, final recovery is not related to the initial angiographic lesions ${ }^{(5)}$.

Considering its good prognosis, we aimed to study the epidemiology of MEWDS to confirm the usefulness of FA as a complementary tool that is accessible at most ophthalmic clinics, which could allow MEWDS-like lesions to be identified more easily, thus ensuring good prognosis, and avoiding unnecessary treatment.

\section{METHODS}

The study consisted of a cross-sectional retrospective analysis of all the FA performed at the retina department from July 2006 to October 2012, including 6111 patients. All exams were analyzed, then the MEWDS-like angiograms were selected. All the cases diagnosed as MEWDS were examined by the retina coordinator, and their FA were reviewed for both the patients' eyes, thus determining the frequency of this disease in the study population and allowing analysis of the angiographic aspects (FA patterns: presence of punctuate hyperfluorescent dots, patchy spots, optic disc leakage of fluorescein, and foveal granularity) detected in each exam. The patients were referred from the ophthalmic emergency room, and those who needed low visual acuity investigation underwent FA exam on the same day, which allowed early-stage lesions to be detected.

Epidemiological data were collected in terms of the patients'age, sex, affected eyes (uni or bilateral), and the chief complaint, including the length of the clinical symptoms.

\section{RESULTS}

Among the 6,111 FA studied, only 0.24\% (15 patients) were diagnosed with MEWDS; 60\% were male (nine patients) and 40\% were female (six patients). The female/male ratio was $0.7 / 1$, which differs from the existing literature ${ }^{(1)}$. The age of the patients ranged from 13 to 42 years.

Chief complaints varied, and included photopsias, central scotomas, and diffuse blurred vision, which disappeared within 1 to 8 weeks from the first symptom until total recovery.

The best-corrected visual acuity varied from 20/20 to 20/200, evolving to 20/20 in 14 (93.3\%) of the patients (Figure 1). The only

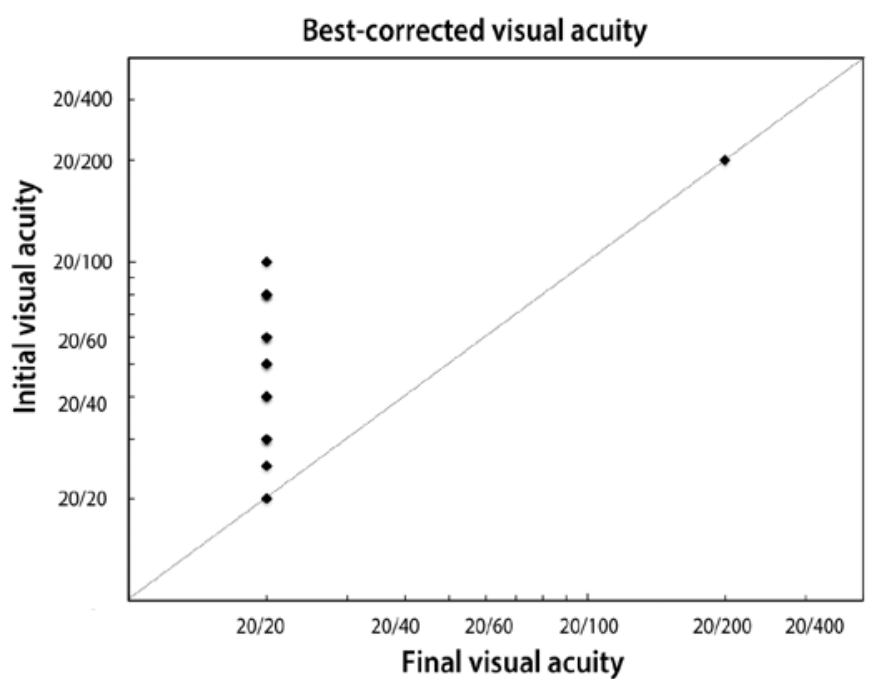

Figure 1. Change in initial visual acuity to final visual acuity in each of the 15 patients diagnosed with MEWDS. patient who did not recover his visual acuity presented multifocal choroiditis (MFC) and MEWDS with permanent macular damage.

The main angiographic findings included: only hyperfluorescent dots $(26.6 \%$, four patients), only hyperfluorescent patchy spots (33.4\%, five patients), and both dots and spots (40\%, six patients). Atypical findings such as optic disc hyperfluorescence were detected in $66.6 \%$ (10 patients). Foveal granularity was detected in $46.6 \%$ (seven patients), with $57.1 \%$ (four patients) of these being female. Multifocal choroiditis association and vasculitis were found in $6.6 \%$ (one patient) (Table 1, Figures 2 and 3). Notably, bilateral hyperfluorescent lesions were detected in all of the patients in this study, even without any symptoms in the fellow eye.

\section{DISCUSSION}

Characteristic FA findings in MEWDS might contribute to its diagnosis, although some atypical FA aspects, such as foveal granularity without the typical white dots and associated vasculitis, were found in this study (Figures 2 and 3)(6,7).

Besides FA, other complementary exams can reveal MEWDS-like lesions, including indocyanine green angiography and autofluorescence exams showing hypocyanescent and hypo-autofluorescent lesions, respectively, which correspond to the white dots and other lesions not detected during ophthalmoscopic examination (8-11).

Table 1. Distribution of the typical and atypical fluorescein angiography lesion patterns observed in patients with MEWDS

\begin{tabular}{lc}
\hline Fluorescein angiography findings & Patients \\
\hline Typical & \\
Hyperfluorescent dots & $26.6 \%$ \\
Hyperfluorescent patchy spots & $33.4 \%$ \\
Associated dots and spots & $40.0 \%$ \\
Atypical & \\
Optic disc hyperfluorescence & $66.6 \%$ \\
Foveal granularity & $46.6 \%$ \\
Multifocal choroiditis & $6.6 \%$ \\
Vasculitis & $6.6 \%$ \\
\hline
\end{tabular}

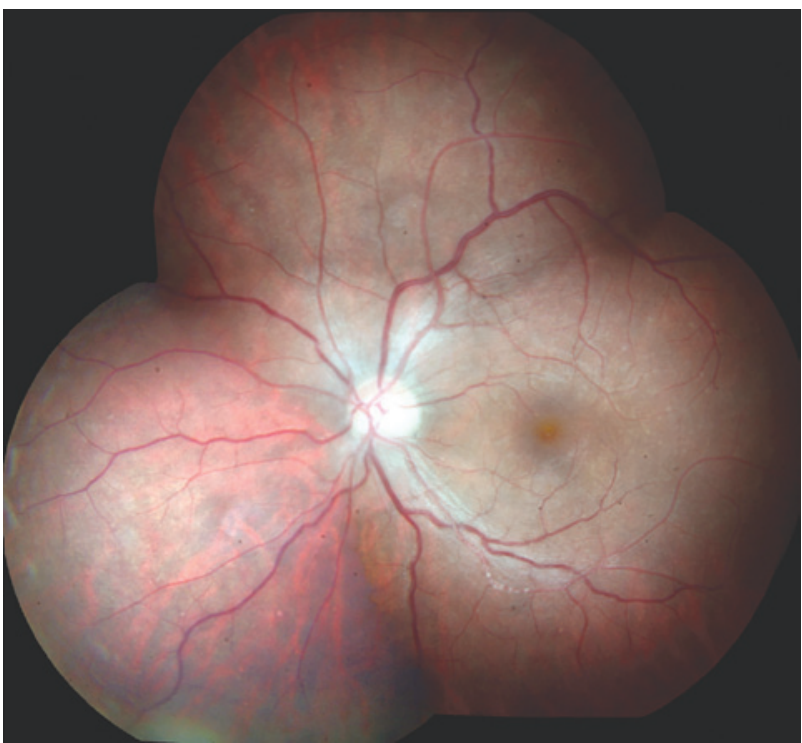

Figure 2. Young male presenting photopsias and blurred vision lasting 4 days (best-corrected visual acuity: 20/40 Snellen). Note the white dots at the posterior pole and associated inferior vasculitis. Total vision acuity recovery was achieved in 4 weeks (author's archive). 

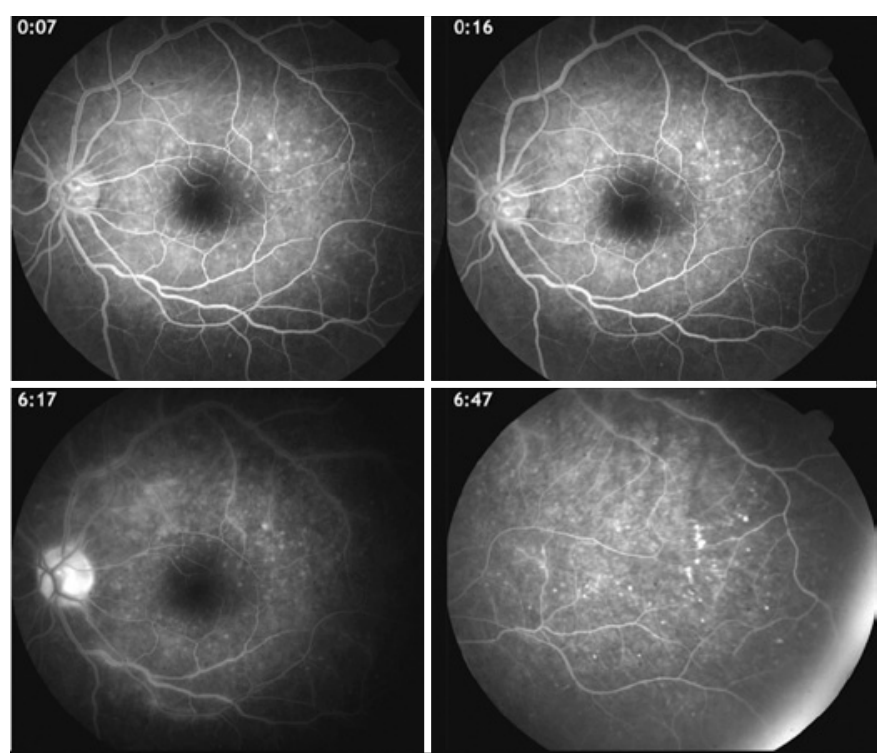

Figure 3. The same patient from figure 2 , showing hyperfluorescent dots in a wreath-like swirl configuration at the posterior pole and temporal periphery. Note the perivascular hyperfluorescence at the inferior blood vessel adjacent to the optic disc (author's archive).

OCT has been used to study the MEWDS macular lesions, to demonstrate that all abnormalities at the inner-outer photoreceptor segments recovered during the course of the disease ${ }^{(12)}$. Spectral domain OCT can detect very small ruptures in the photoreceptor layer in MEWDS cases ${ }^{(13,14)}$. However, there is strong evidence that, even with unilateral symptoms, the photoreceptor layer changes in both eyes, restoring itself spontaneously, as was shown in most of the FA findings in this study ${ }^{(15)}$

Studies on the association of MEWDS with other diseases have mainly focused on MFC, revealing cases of simultaneous MEWDS and MFC, although MFC can sometimes occur months after MEWDS(15-17). MEWDS has also been associated with acute idiopathic blind spot enlargement syndrome, acute macular neuroretinopathy, and acute zonal occult outer retinopathy ${ }^{(18-20)}$

There are rare and isolated cases of postvaccinal MEWDS related to hepatitis B, meningitis, and human papillomavirus vaccines, although there is no confirmed infectious etiological relationship ${ }^{(21,22)}$.

In terms of the low frequency of MEWDS in our study population, with 15 MEWDS patients diagnosed from the 6111 FA performed $(0.24 \%)$, larger studies and meta-analyses may be necessary in order to follow up these patients and ensure good prognosis. This is important because some patients can relapse, sometimes years after the first episode ${ }^{(6)}$. An interesting feature found in this study was the higher frequency in male patients (60\% male to $40 \%$ female), which contradicts the female predominance found in the existing literature ${ }^{(18)}$.

The angiographic characteristics, either from FA or indocyanine green angiography, can vary in patients with similar visual complaints. According to previous studies, the reason for this is that there are many other ocular structures involved in the physiopathology of this disease ${ }^{(5)}$. Moreover, it is important to highlight that, in apparently normal fundoscopy patients with scotomas and photopsias, dots and spots at the near peripheral retina can be found via FA, suggesting MEWDS. In this study, both eyes were affected in all of the patients, even without any symptoms in the fellow eye. The eyes without symptoms showed discrete lesions (hyperfluorescent dots and spots), thus also suggesting MEWDS. Therefore, careful examination by an experienced retina specialist is imperative in order to detect discrete lesions during clinical examination.

On the other hand, many types of infectious retinitis may be masked by MEWDS. This could be true for some patients in this study that were not followed up after recovery, thus resulting in data that differs from those in previous reports ${ }^{(21-23)}$.

MFC associated with MEWDS has been detected in some studies, and was also found in the present study (6.6\% of the patients studied). On the other hand, MEWDS lesions are known to disappear spontaneously, while MFC leaves choroidoretinal scars. The relationship between MFC and MEWDS may indicate a common etiological factor ${ }^{(16)}$. In these cases, multifocal electroretinogram can help to differentiate MFC from MEWDS, with deep wave depression in MFC and an initial focal loss in MEWDS, followed by full recovery of retinal function at about 7-14 days ${ }^{(24,25)}$.

\section{CONCLUSION}

MEWDS is an uncommon but self-limiting disease with good prognosis, which can be associated with other immunological diseases. In this study, $93.3 \%$ of the patients recovered total vision, confirming the good prognosis of this syndrome.

FA needs to be emphasized as a useful complementary tool for MEWDS diagnosis, even to confirm or to exclude differential diagnoses such as acute posterior multifocal placoid pigment epitheliopathy, Birdshot chorioretinopathy, diffuse unilateral subacute neuroretinitis, and the other diseases that comprise the white dot syndromes. The present study allowed easier detection of MEWDS-like lesions through FA in association with the patient's clinical history and follow-up, thus characterizing the course of the disease, which has a good prognosis. Note that FA patterns might vary in each patient, including hyperfluorescent dots and/or patchy spots, hyperfluorescent optic disc, and foveal granularity, which were the most common FA findings in this study. Possible variations from the complementary exams should also be considered. In conclusion, MEWDS is not often diagnosed in Rio de Janeiro, which is probably due to patients' later arrival for ophthalmic assistance and lack of recognition at the emergency fundoscopy examination. Nevertheless, it is important to consider the methodological weaknesses of retrospective studies.

\section{REFERENCES}

1. Jampol LM, Sieving PA, Pugh D, Fishma GA, Gilbert H. Multifocal evanescent white dot syndrome. I. Clinical findings. Arch Ophthalmol. 1984;102(5):671-4.

2. Takeda M, Kimura S, Tamiya M. Acute disseminated retinal pigment epitheliopathy. Folia Ophthalmol Jpn. 1984;35:2613-20.

3. Forooghian F, Stetson PF, Gross NE, Meyerle CB. Quantitative assessment of photoreceptor recovery in atypical multiple evanescent white dot syndrome. Ophthalmic Surg Lasers Imaging. 2010;41 Suppl:S77-80.

4. Ryan PT. Multiple evanescent white dot syndrome: a review and case report. Clin Exp Optom. 2010;93(5):324-9.

5. Dell'omo R, Wong R, Marino M, Konstantopoulou K, Pavesio C. Relationship between different fluorescein and indocyanine green angiography features in multiple evanescent white dot syndrome. Br J Ophthalmol. 2010;94(1):59-63.

6. Abu-Yaghi NE, Hartono SP, Hodge DO, Pulido JS, Bakri SJ. White dot syndromes: a 20-year study of incidence, clinical features, and outcomes. Ocul Immunol Inflamm. 2011;19(6):426-30

7. Shelsta HN, Rao RR, Bhatt HK, Jampol LM. Atypical presentations of multiple evanescent white dot syndrome without white dots: a case series. Retina. 2011;31(5):973-6. Comment in: Retina. 2013;33(3):669. Retina. 2013;33(3):668-9.

8. Schelfhout V, Lafaut B, Van den Neste C, Kestelyn P, De Laey JJ. Multiple evanescent white dot syndrome. Bull Soc Belge Ophtalmol. 1998;270:19-23.

9. Sisk RA, Wykoff CC, Albini TA. Comment on "fundus autofluorescence and multiple evanescent white dot syndrome." Retina. 2009;29(9):1377-8; author reply 1378-9. Comment on: Retina. 2009:29(1):60-3.

10. Desarnaulds AB, Borruat FX, Herbort CP, de Courten C. Indocyanine green angiography in "multiple evanescent white dot syndrome" (MEWDS). Klin Monbl Augenheilkd. 1998;212(5):318-20.

11. Obana A, Kusumi M, Miki T. Indocyanine green angiographic aspects of multiple evanescent white dot syndrome. Retina. 1996;16(2):97-104.

12. Hangai $M$, Fujimoto $M$, Yoshimura N. Features and function of multiple evanescent white dot syndrome. Arch Ophthalmol. 2009;127(10):1307-13.

13. Nguyen MH, Witkin AJ, Reichel E, Ko TH, Fujimoto JG, Schuman JS, Duker JS. Microstructural abnormalities in MEWDS demonstrated by ultrahigh resolution optical coherence tomography. Retina. 2007;27(4):414-8

14. Silva RA, Albini TA, Flynn HW Jr. Multiple evanescent white dot syndromes. J Ophthalmic Inflamm Infect. 2012;2(2):109-11. 
15. Li D, Kishi S. Restored photoreceptor outer segment damage in multiple evanescent white dot syndrome. Ophthalmology. 2009;116(4):762-70.

16. Schaal S, Schiff WM, Kaplan HJ, Tezel TH. Simultaneous appearance of multiple evanescent white dot syndrome and multifocal choroiditis indicate a common causal relationship. Ocul Immunol Inflamm. 2009:17(5):325-7.

17. Bryan RG, Freund KB, Yannuzzi LA, Spaide RF, Huang SJ, Costa DL. Multiple evanescen white dot syndrome in patients with multifocal choroiditis. Retina. 2002;22(3):317-22

18. Gass JD. Acute zonal occult outer retinopathy. Donders Lecture: The Netherlands Ophthalmological Society, Maastricht, Holland, June 19, 1992. J Clin Neuroophthalmol. 1993;13(2):79-97.

19. Singh K, de Frank MP, Shults WT, Watzke RC. Acute idiopathic blind spot enlargement. A spectrum of disease. Ophthalmology. 1991;98(4):497-502.

20. Gass JD, Hamed LM. Acute macular neuroretinopathy and multiple evanescent white dot syndrome occurring in the same patients. Arch Ophthalmol. 1989;107(2):189-93.
21. Cohen SM. Multiple Evanescent White Dot Syndrome after vaccination for human papilloma virus and meningococcus. J Pediatr Ophthalmol Strabismus. 2009 Jun 25. doi: 10.3928/01913913-20090616-01.

22. Baglivo E, Safran AB, Borruat FX. Multiple evanescent white dot syndrome after hepatitis B vaccine. Am J Ophthalmol. 1996;122(3):431-2

23. Stangos A, Zaninetti M, Petropoulos I, Baglivo E, Pournaras C. Multiple evanescent white dot syndrome following simultaneous hepatitis-A and yellow fever vaccination. Ocul Immunol Inflamm. 2006;14(5):301-4

24. Feigl B, Haas A, El-Shabrawi Y. Multifocal ERG in multiple evanescent white dot syndrome. Graefes Arch Clin Exp Ophthalmol. 2002;240(8):615-21.

25. Oh KT, Folk JC, Maturi RK, Moore P, Kardon RH. Multifocal electroretinography in multifocal choroiditis and the multiple evanescent white dot syndrome. Retina. 2001; 21(6):581-9.

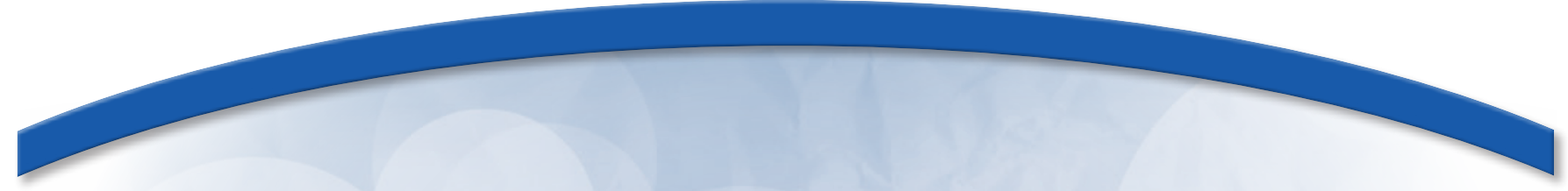

18ㅇ Congresso de Oftalmologia da Clínica Oftalmológica da FMUSP

$17^{\circ}$ Congresso de Auxiliar de Oftalmologia

\author{
4 e 5 de dezembro de 2015
}

São Paulo - SP

Informações:

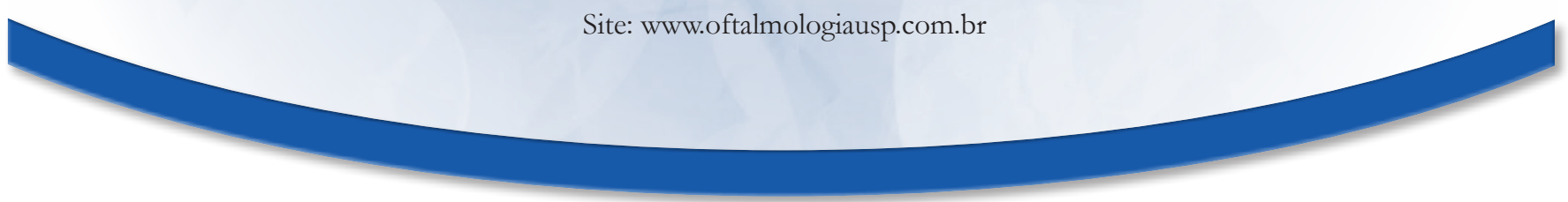

